\title{
Hydrosilylation Reactions Catalyzed by Rhenium
}

\author{
Duo Wei ${ }^{1,2}$, Ruqaya Buhaibeh ${ }^{2}$, Yves Canac ${ }^{2}$ (D) and Jean-Baptiste Sortais ${ }^{2,3, *(D)}$ \\ 1 University Rennes, CNRS, ISCR-UMR 6226, 35000 Rennes, France; Duo.Wei@catalysis.de \\ 2 LCC-CNRS, Université de Toulouse, UPS, 31400 Toulouse, France; ruqaya.buhaibeh@lcc-toulouse.fr (R.B.); \\ yves.canac@lcc-toulouse.fr (Y.C.) \\ 3 Institut Universitaire de France 1 rue Descartes, CEDEX 05, 75231 Paris, France \\ * Correspondence: jean-baptiste.sortais@lcc-toulouse.fr
}

Citation: Wei, D.; Buhaibeh, R.;

Canac, Y.; Sortais, J.-B.

Hydrosilylation Reactions

Catalyzed by Rhenium. Molecules

2021, 26, 2598. https://doi.org/

$10.3390 /$ molecules 26092598

Academic Editor: Vincent Ritleng

Received: 17 March 2021

Accepted: 15 April 2021

Published: 29 April 2021

Publisher's Note: MDPI stays neutral with regard to jurisdictional claims in published maps and institutional affiliations.

Copyright: (C) 2021 by the authors. Licensee MDPI, Basel, Switzerland. This article is an open access article distributed under the terms and conditions of the Creative Commons Attribution (CC BY) license (https:/ / creativecommons.org/licenses/by/ $4.0 /)$.

\begin{abstract}
Hydrosilylation is an important process, not only in the silicon industry to produce silicon polymers, but also in fine chemistry. In this review, the development of rhenium-based catalysts for the hydrosilylation of unsaturated bonds in carbonyl-, cyano-, nitro-, carboxylic acid derivatives and alkenes is summarized. Mechanisms of rhenium-catalyzed hydrosilylation are discussed.
\end{abstract}

Keywords: rhenium; hydrosilylation; unsaturated bonds; carbonyls; alkenes

\section{Introduction}

Hydrosilylation is a very versatile transformation consisting of the addition of a hydrosilane $\left(\mathrm{H}-\mathrm{SiR}_{3}\right)$ to an unsaturated bond. Organosilicon compounds have found widespread applications in our daily lives in silicon-based materials such as silicon rubbers, adhesives, paper release coating, and so forth. In addition, hydrosilylation is an atom economic reaction to access valuable organosilane intermediates for fine chemical synthesis [1,2]. For many years, platinum has been the metal of choice for designing hydrosilylation catalysts, Speier's, Karstedt's or Markó's catalysts being the most representative examples (Figure 1). Other noble transition metals, such as rhodium, ruthenium, iridium or palladium, have also been used in this transformation [3]. However, the limited availability of these precious transition metals has prompted researchers to explore alternatives metals in the periodic table, in particular first row transition metals such as iron, cobalt and nickel [4-6].
$\mathrm{H}_{2} \mathrm{PtCl}_{6}$<smiles></smiles>

Speier's catalyst

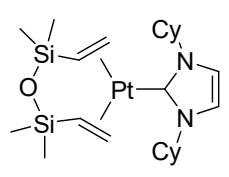

Marko's catalyst
Figure 1. Representative platinum-based hydrosilylation catalysts.

In this regard, group 7 transition metals, manganese [7] and rhenium [8], were not an obvious choice at first glance. Indeed, rhenium complexes, in particular oxo-rhenium compounds, have been mainly recognized as efficient catalysts in oxidations, such as epoxidation or oxygen atom transfer reactions [9-14]. This is highlighted by organo-rhenium(VII) trioxide, particularly methyltrioxorhenium $\left(\mathrm{MeReO}_{3}\right.$, abbreviated as $\left.\mathrm{MTO}\right)$, arguably one of the most versatile transition metal catalysts known to date. Rhenium is also well-known to promote olefin metathesis [15] or aldehyde olefinations [16]. In complement, the coordination chemistry of rhenium was explored for the potential application of ${ }^{186 / 188} \operatorname{Re}$ radioisotopes in nuclear medicine and bio-medical chemistry $[17,18]$. 
The application of rhenium derivatives in hydrosilylation $[19,20]$ was not unveiled until 2003 [21,22]. Since the application of the lighter congener of rhenium, namely manganese, has been increasing lately in hydrosilylation $[23,24]$, we report here the evolution of rhenium in this catalytic transformation.

\section{Hydrosilylation of $\mathrm{C}=\mathrm{O}, \mathrm{C}=\mathrm{N}, \mathrm{C} \equiv \mathrm{N}$ and $\mathrm{NO}_{2}$ Bonds}

\subsection{Hydrosilylation of Carbonyl Derivatives}

The first rhenium-catalyzed hydrosilylation was described in 2003 by Toste et al. (Scheme 1a). This seminal contribution represents the first example of a hydrosilylation catalyst with a high-valent metal bearing two terminal oxo ligands, reversing the traditional use of metal-oxo complexes in catalysis. Indeed, the hydrosilylation of aldehydes and ketones was promoted by the readily available iododioxo(bistriphenylphosphine)rhenium(V) complex $\left[\left(\mathrm{PPh}_{3}\right)_{2} \operatorname{Re}(\mathrm{O})_{2} \mathrm{I}\right](\mathrm{C} 1)[21,22]$. The scope of this reaction included aromatic or aliphatic ketones and aldehydes with a good tolerance of functional groups (amino, nitro, halo, ester, cyano, cyclopropyl and alkene groups remained untouched). This air and moisture tolerant reaction provides silyl-protected alcohols in a straightforward reductionprotection protocol as bulky hydrosilanes were used $\left(\mathrm{HSiMe}_{2} \mathrm{Ph}, \mathrm{HSiEt}_{3}, \mathrm{HSiMe}_{2} \mathrm{Ph}\right.$ and $\mathrm{HSitBuMe}_{2}$ ).

A detailed mechanism, supported by experimental evidence, was proposed by the same group [21,25] and confirmed by a computational study by Wu et al. in 2006 [26] (Scheme 1b). The first step involves the formal [2+2] addition of silane to the $\mathrm{Re}=\mathrm{O}$ bond in $\mathbf{C 1}$ to produce metal hydride I-1, which was isolated and characterized by X-ray diffraction. Alkoxy-metal intermediate I-3 is produced by the addition of rhenium hydride to the carbonyl group. Transfer of the silyl group to the alkoxy ligand, formally a retro-[2+ 2] reaction, forms the silyl ether product and regenerates the dioxo catalyst $\mathbf{C 1}$.

a)

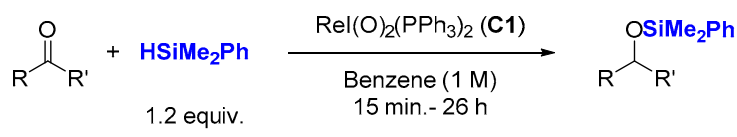

$$
\begin{aligned}
& \text { Aldehydes, } \mathbf{C} 1(2.0 \mathrm{~mol} \%) \text {, r.t. }-60^{\circ} \mathrm{C}, 9 \text { examples, } 73-95 \% \text { yields } \\
& \text { Ketones, C1 }(5.0 \mathrm{~mol} \%), 60 \text { or } 70^{\circ} \mathrm{C}, 6 \text { examples, } 63-87 \% \text { yields }
\end{aligned}
$$
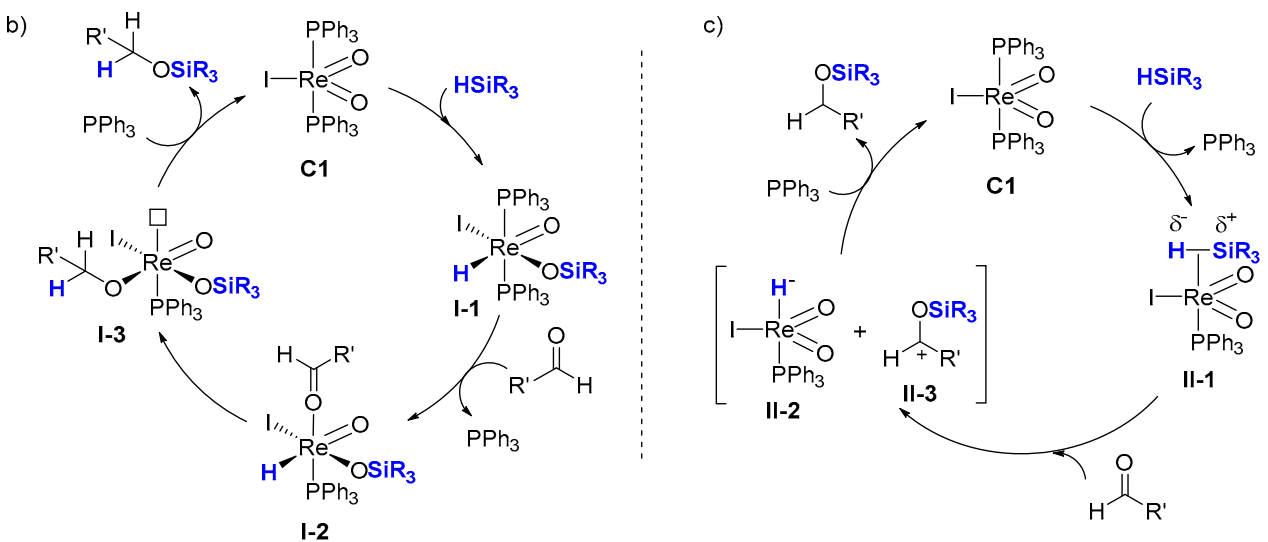

Scheme 1. $\operatorname{ReI}(\mathrm{O})_{2}\left(\mathrm{PPh}_{3}\right)_{2}(\mathrm{C} \mathbf{1})$ catalyzed hydrosilylation of carbonyl compounds with related mechanism studies. (a) Scope of the reaction; (b) Proposed [2 + 2] addition mechanistic pathway; (c) Proposed ionic outer-sphere mechanistic pathway.

However, the computational study by Wei [27] showed that the ionic outer-sphere mechanistic pathway (Scheme 1c) is energetically more favorable than the [2+2] addition mechanism supported by $\mathrm{Wu}$ for the $\mathbf{C}$. In this alternative mechanism, the activation of $\mathrm{Si}-\mathrm{H}$ goes through $\eta^{1}$-bonding of silane to the metal center followed by a nucleophilic 
addition of the organic substrate on the Si center in II-1 to cleave the $\mathrm{Si}-\mathrm{H}$ bond forming the anionic rhenium hydride II-2 and the activated organic substrate II-3. Finally, hydride transfer from the rhenium metal II-2 to the carbon atom of the organic substrate II-3 produces the desired product and regenerates complex $\mathbf{C 1}$.

Intrigued by the work of Toste, Royo et al. explored in 2005 the catalytic activity of a family of oxo-rhenium complexes (C2-C7, Scheme 2) [28]. All these complexes showed activity in the reduction of aliphatic and aromatic aldehydes (six examples) and ketones (four examples) with dimethylphenylsilane in $\mathrm{C}_{6} \mathrm{D}_{6}$ solution (Scheme 2), demonstrating the general ability of oxo-rhenium complexes to promote hydrosilylation. Notably, C2 catalyzes the hydrosilylation of aldehydes at room temperature, within $30 \mathrm{~min}$, affording the corresponding silyl ethers in a good yield, but is ineffective as a ketone hydrosilylation catalyst (even at $\left.80{ }^{\circ} \mathrm{C}\right)$. C5-C7 $(5.0 \mathrm{~mol} \%)$ are active for the hydrosilylation of 4-trifluoromethylbenzaldehyde at $80{ }^{\circ} \mathrm{C}$, giving $40 \%$ yield $(\mathbf{C} 5,20 \mathrm{~h}),>95 \%$ yield $(\mathbf{C} 6,10 \mathrm{~h})$ and $>95 \%$ yield $(\mathbf{C} 7,10 \mathrm{~h})$, respectively.

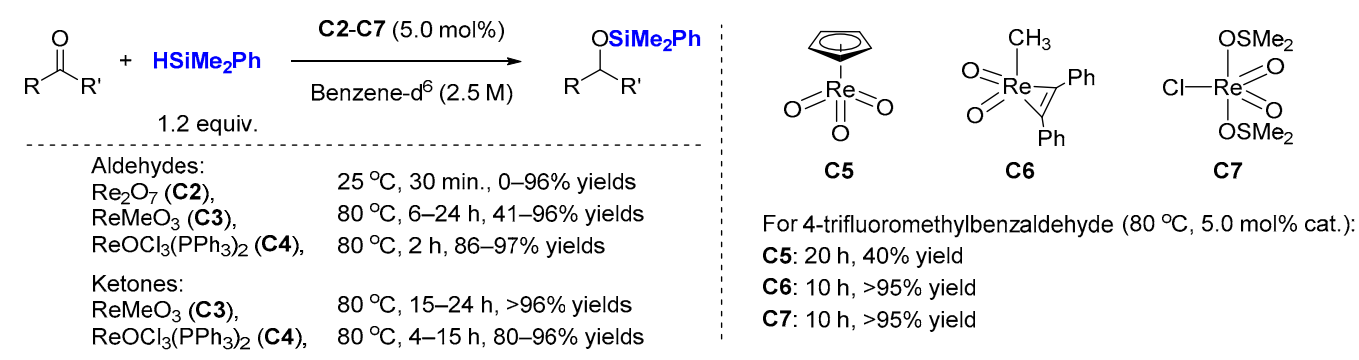

Scheme 2. Reduction of carbonyl groups by high-valent rhenium oxides C2-C7.

In the same year, Abu-Omar and co-workers reported a new system for the hydrosilylation of aldehydes and ketones using a mono-oxorhenium $(\mathrm{V})$ catalyst $(\mathrm{C} 8)$ containing two oxazoline ligands (Scheme 3) $[29,30]$. The reaction proceeds efficiently under ambient temperatures with low catalyst loading $(0.1 \mathrm{~mol} \%), 1.5$ equiv. $\mathrm{HSiEt}_{3}$ using $\mathrm{CH}_{2} \mathrm{Cl}_{2}$ as a solvent or without a solvent. Interestingly, the catalyst preserves its activity after being recycled (for 2-butanone, 80\% NMR yield (1st cycle) and 50\% NMR yield (2nd cycle)).

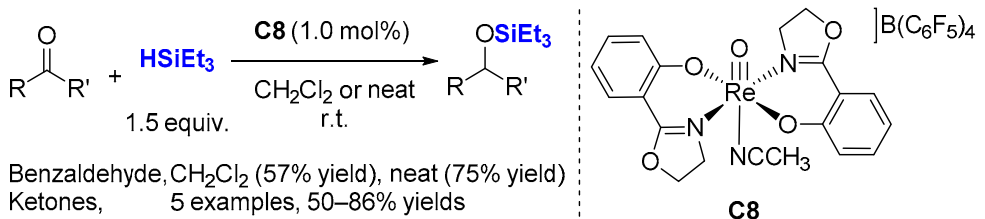

Ketones, 5 examples, $50-86 \%$ yields $\quad$ C8

Scheme 3. Reduction of carbonyl groups by oxazoline containing rhenium oxide C8.

Then, Abu-Omar and co-workers prepared a number of cationic oxorhenium(V) salen based complexes such as $[\operatorname{Re}(\mathrm{O})(\mathrm{salpn})(\mathrm{Solv})]\left[\mathrm{B}\left(\mathrm{C}_{6} \mathrm{~F}_{5}\right)_{4}\right] \mathrm{C}$ 9 [31,32] in 2006 (Scheme 4a) and $\left[\mathrm{ReO}\right.$ (saldach) $\left.\left(\mathrm{H}_{2} \mathrm{O}\right)\right]\left[\mathrm{B}\left(\mathrm{C}_{6} \mathrm{~F}_{5}\right)_{4}\right] \mathrm{C10}$ [33] in 2008 incorporating a chiral environment, (Scheme 4 b). C9 and C10 serve as good catalysts for hydrosilylation of carbonyl compounds ( $1.0 \mathrm{~mol} \%$ cat. loading, 1.5 equiv. silane, room temperature (r.t.), although asymmetric versions $(\mathbf{C 1 0})$ of these reactions afford poor enantioselectivity, even in the presence of bulky silane such as $\mathrm{HSitBuMe}_{2}$. 
a)

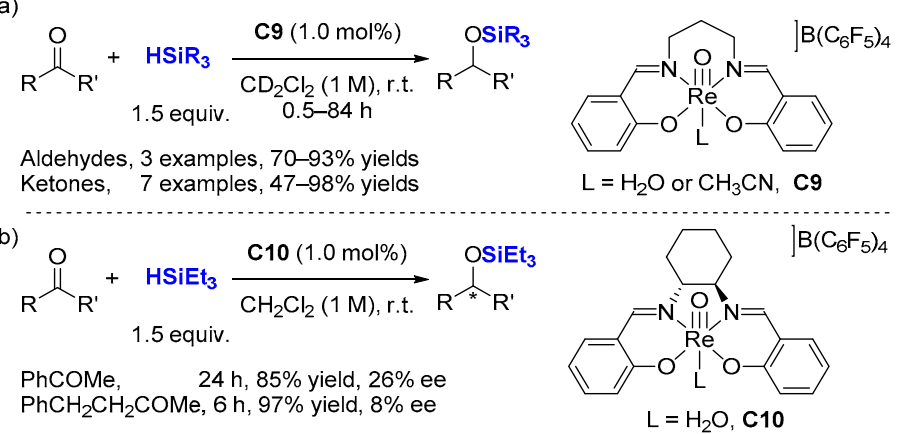

Scheme 4. Hydrosilylation of carbonyl compounds with cationic oxorhenium(V) non chiral salen (a) and chiral salen $(\mathbf{b})$ based complexes.

The mechanism of action of these high-valent mono-oxo-rhenium(V) catalysts was investigated, providing new insights [34] including via a theoretical study [35-37]. The addition of silane across the Re-O multiple bond was not observed in mono-oxo-rhenium( $\mathrm{V})$ complex $\operatorname{Re}(\mathrm{O}) \mathrm{Cl}_{3}\left(\mathrm{PPh}_{3}\right)_{2}(\mathrm{C} 4)$ catalyzing the hydrosilylation of carbonyls. Furthermore, they observed that silanes slowly reacted with $\mathbf{C} 4$ to give the isolated hydride intermediate $\mathrm{Re}(\mathrm{O}) \mathrm{Cl}_{2} \mathrm{H}\left(\mathrm{PPh}_{3}\right)_{2}$ (III-1). However, this isolated hydride intermediate is not sufficiently reactive to account for the catalytic turnover, as only $20 \%$ yield of the silyl ether product is observed (Scheme 5 left). These observations lead the authors to propose that the reaction pathway involves the formation of a $\eta^{2}$-silane complex (IV-1), followed by the heterolytic cleavage of the $\mathrm{Si}-\mathrm{H}$ bond at the rhenium center after elimination of one $\mathrm{PPh}_{3}$ ligand (Scheme 5, right). This ionic mechanism involves the sequential transfer of a silyl ion $\left(\mathrm{R}_{3} \mathrm{Si}^{+}\right)$and then a hydride to a polar double bond to furnish the reduction reactions. In this proposed catalytic cycle, neither the coordination of unsaturated substrates to the metal center nor its insertion into the $\mathrm{M}-\mathrm{H}$ bond is involved.

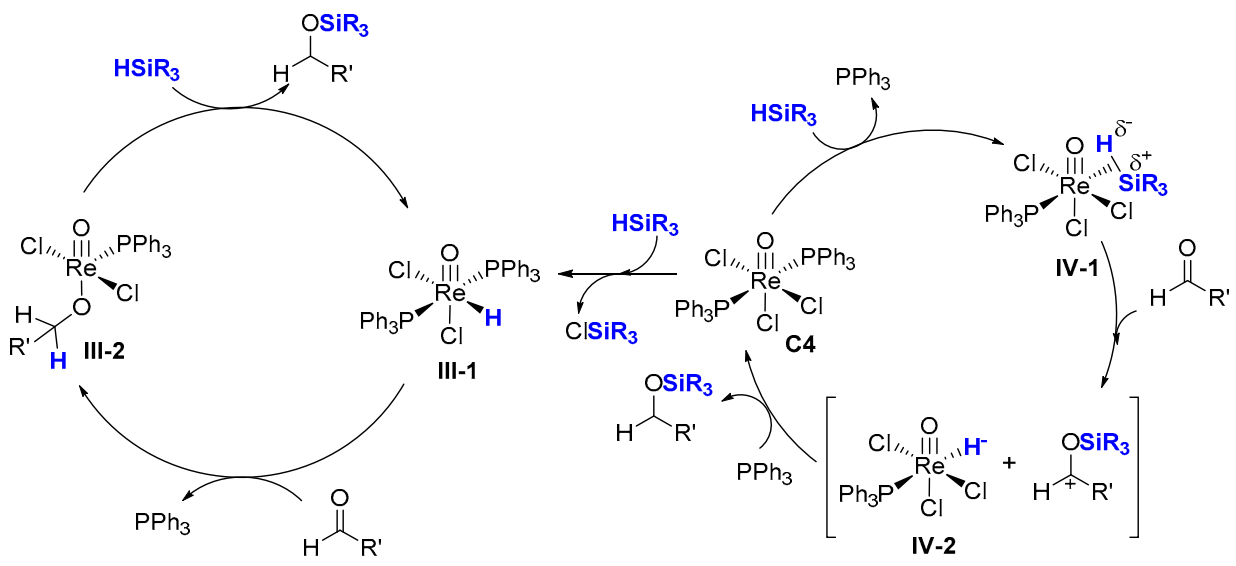

Scheme 5. The $\sigma$-bond metathesis pathway involving the isolated hydride intermediate $\operatorname{Re}(\mathrm{O}) \mathrm{Cl}_{2} \mathrm{H}\left(\mathrm{PPh}_{3}\right)_{2}$ (left). The pathway involving a $\eta^{2}$-silane complex (right).

The enantioselective reduction of prochiral ketones [38] and imines [39] with 2 equiv. $\mathrm{HSiMe}_{2} \mathrm{Ph}$ was reported by Toste (Scheme 6$)$ using chiral (CN-box)Re(V)-oxo complexes (3.0 $\mathrm{mol} \%, \mathrm{CN}-\mathrm{Box}=$ cyanobis(oxazoline)). These reduction reactions proceed under an ambient air atmosphere with a highly functional group tolerant with ees of up to $>99 \%$. The $(\mathrm{CNbox}) \operatorname{Re}(\mathrm{V})$-oxo complexes $(\mathrm{C} 12)$ can be prepared by simply stirring $\mathbf{L 1}$ with $\operatorname{Re}(\mathrm{O}) \mathrm{Cl}_{3}\left(\mathrm{OPPh}_{3}\right)\left(\mathrm{SMe}_{2}\right)(\mathrm{C} 11)$ in $\mathrm{CH}_{2} \mathrm{Cl}_{2}$ at r.t. and isolated as a green stable solid (Scheme 6a) or generated directly in situ. 


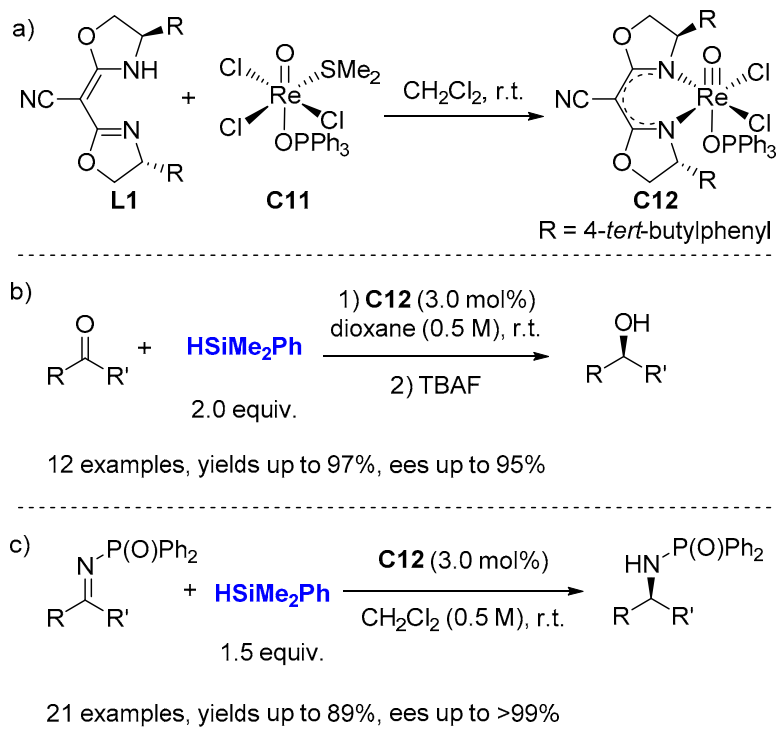

Scheme 6. Enantioselective reduction of ketones (b) and imines (c) catalyzed by (CN-Box) $\operatorname{Re}(\mathrm{V})-$ oxo complexes C12 (a).

Similarly, a theoretical investigation of the mechanism for the high-valent mono-oxorhenium $(\mathrm{V})$ hydride $\mathrm{Re}(\mathrm{O}) \mathrm{HCl}_{2}\left(\mathrm{PPh}_{3}\right)_{2}$ (III-1) catalyzed hydrosilylation of $\mathrm{C}=\mathrm{N}$ functionalities was performed by Wei and co-workers [40]. These results suggest that an ionic $\mathrm{S}_{\mathrm{N}} 2-\mathrm{Si}$ outer-sphere pathway proceeding via the heterolytic cleavage of the $\mathrm{Si}-\mathrm{H}$ bond competes with the hydride pathway featuring the $\mathrm{C}=\mathrm{N}$ bond inserted into the Re- $\mathrm{H}$ bond.

Besides these oxorhenium complexes, a series of novel low-valent Re(III) complexes were synthesized by Ison et al., such as C13 [41] in 2012 and C14 [42] in 2017 (Scheme 7a). C14 $(0.03 \mathrm{~mol} \%$, r.t. $)$ is more reactive than $\mathrm{C} 13\left(0.1 \mathrm{~mol} \%, 80^{\circ} \mathrm{C}\right)$ for the hydrosilylation of aldehydes [42]. Excellent NMR yields (65-100\%, 13 examples) were achieved at ambient temperature under neat conditions using dimethylphenylsilane with $\mathbf{C 1 4}$. The reaction affords TONs of up to 9200 and a TOF of up to $126 \mathrm{~h}^{-1}$ (Scheme 7a).

Based on kinetic and mechanistic studies, an ionic outer-sphere mechanism for the catalytic hydrosilylation of benzaldehyde by $\mathbf{C 1 4}$ has been proposed (Scheme $7 \mathrm{~b}$ ). First, silane is activated through $\eta^{1}(\mathbf{V}-2)$ or $\eta^{2}\left(\mathbf{V}-2^{\prime}\right)$ coordination to the rhenium center. Then, the aldehyde substrate attacks the Si center in $(\mathbf{V}-2)$ or $\left(\mathbf{V}-2^{\prime}\right)$ to prompt the heterolytic cleavage of the $\mathrm{Si}-\mathrm{H}$ bond yielding an ion pair, the hydride complex V-3 and a silylated aldehyde ion. Finally, hydride transfer from rhenium to the carbonyl carbon of the activated substrate completes the catalytic cycle [43].

Berke and co-workers reported several easily available nitrosyl-rhenium complexes, for example, $\operatorname{Re}(\mathrm{H})\left(\mathrm{PiPr}_{3}\right)_{2}(\mathrm{NO})\left(\mathrm{NOB}\left(\mathrm{C}_{6} \mathrm{~F}_{5}\right)_{3}\right)(\mathrm{C} 15)[44]$ in 2005, $\operatorname{Re}(\mathrm{H})_{2}\left(\eta^{2}-\mathrm{C}_{2} \mathrm{H}_{4}\right)_{3}(\mathrm{NO})\left(\mathrm{PR}_{3}\right)_{2}$ (C16, $\mathrm{R}=i \mathrm{Pr}, \mathbf{C 1 7}, \mathrm{R}=\mathrm{Cy}$ ) [45] in 2008, $\mathrm{Re}\left(\mathrm{CH}_{3} \mathrm{CN}\right)_{3} \mathrm{Br}_{2}(\mathrm{NO})$ (C18) [46] in 2009, $\operatorname{Re}\left(\mathrm{CH}_{3} \mathrm{CN}\right)_{3} \mathrm{Cl}_{2}$ (NO) (C19) [47] and $\operatorname{Re}\left(\mathrm{CH}_{3} \mathrm{CN}\right) \mathrm{Cl}_{2}(\mathrm{NO})(\mathrm{PCy})_{2}$ (C20) [47] in 2011. Those nitrosyl rhenium complexes were employed in the catalytic hydrosilylation of a variety of carbonyl compounds (Scheme 8a). Hydrosilylations of carbonyl compounds were carried out with the catalyst $\mathrm{C} 15, \mathrm{HSiR}_{3}$ (1 equiv., $\mathrm{R}=\mathrm{Et}$ or $\mathrm{Ph}$ ) from r.t. to $70^{\circ} \mathrm{C}$ either in toluene or under solvent-free conditions. TONs up to 9000 and TOFs up to $22,500 \mathrm{~h}^{-1}$ were observed. C16 and C17 exhibited similar activity in hydrosilylation of acetophenone $(0.5 \mathrm{~mol} \%$ cat. loading at $70{ }^{\circ} \mathrm{C}$ in toluene- $d_{8}$, giving full conv. and TOF up to $800 \mathrm{~h}^{-1}$ ). 
a)

$$
\begin{aligned}
& \underbrace{\mathrm{C}_{6} \mathrm{~F}_{5}}_{\mathrm{C13}} \underset{\mathrm{CH}_{3} \mathrm{CN} \text {, r.t., } 5 \text { min. }}{\mathrm{HBF}_{4} \text { (1 equiv.) }}
\end{aligned}
$$

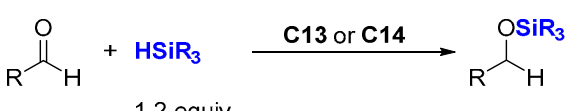

C13: $0.1-0.01 \mathrm{~mol} \%$, r.t. or $80^{\circ} \mathrm{C}, 2-53 \mathrm{~h}, 8$ examples, $79-98$ yields

C14: $0.03 \mathrm{~mol} \%$, neat, r.t., $18-48 \mathrm{~h} 13$ examples, $65-100 \mathrm{NMR}$ yields

b)

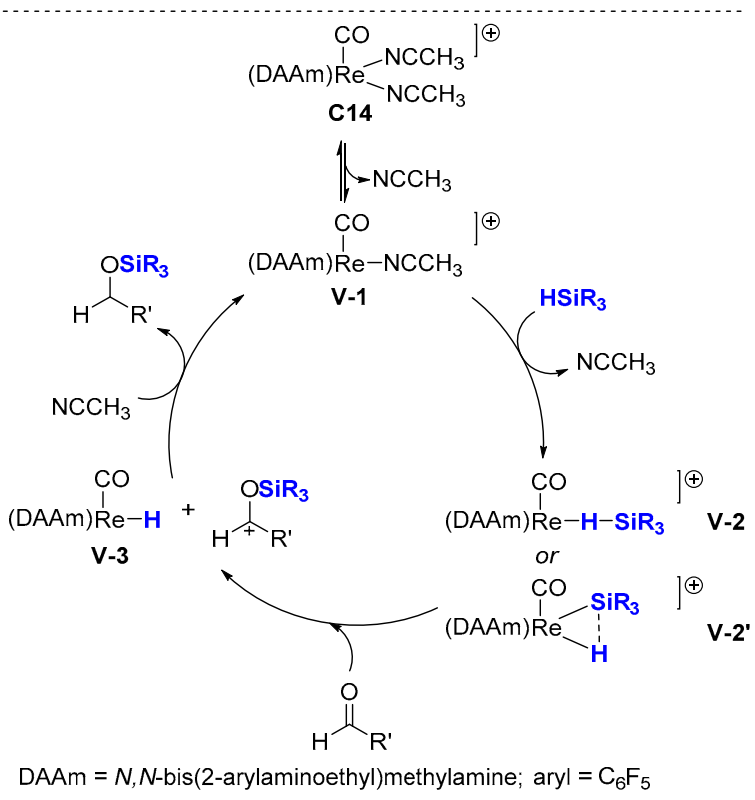

Scheme 7. Cationic rhenium complex catalyzed hydrosilylation of aldehydes. (a) Scope of the reaction; (b) Proposed mechanism.

For C18, chlorobenzene was found to be superior to all the other solvents used. Various aliphatic and aromatic silanes were tested. Excellent yields were achieved at r.t. in dichloromethane using triethylsilane, the reaction affording TOF values of up to $495 \mathrm{~h}^{-1}$.

Phosphine-free complex C19 proved to be less effective than the bisphosphine derivative $\mathbf{C 2 0}$, as the reaction of benzophenone and $\mathrm{Et}_{3} \mathrm{SiH}$ (1.12 equiv.) with $1.0 \mathrm{~mol} \%$ of $\mathrm{C19}$ was carried out at $80{ }^{\circ} \mathrm{C}$, a conversion of less than $10 \%$ was achieved within $4 \mathrm{~h}$, while in the same conditions, $\mathbf{C 2 0}$ gave a $99 \%$ yield.

A possible mechanism for the hydrosilylation of ketones catalyzed by C18 was proposed (Scheme $8 \mathrm{~b}$ ). The initial step consists of the dissociation of a $\mathrm{CH}_{3} \mathrm{CN}$ ligand to generate the pre-catalyst VI-1 followed by the coordination of the silane to the rhenium center to form a $\eta^{2}$-silane complex VI-2. Displacement of a second $\mathrm{CH}_{3} \mathrm{CN}$ ligand by the ketone at the rhenium center yields complex VI-3. The silyl-oxy complex VI-4 could be obtained either from the transfer of a hydride from the silane to the ketone atom or from the oxidative addition of the silane followed by a $\beta$-hydride transfer process. Finally, the reductive elimination step produces the siloxy product and regenerates the pre-catalyst VI-1. 


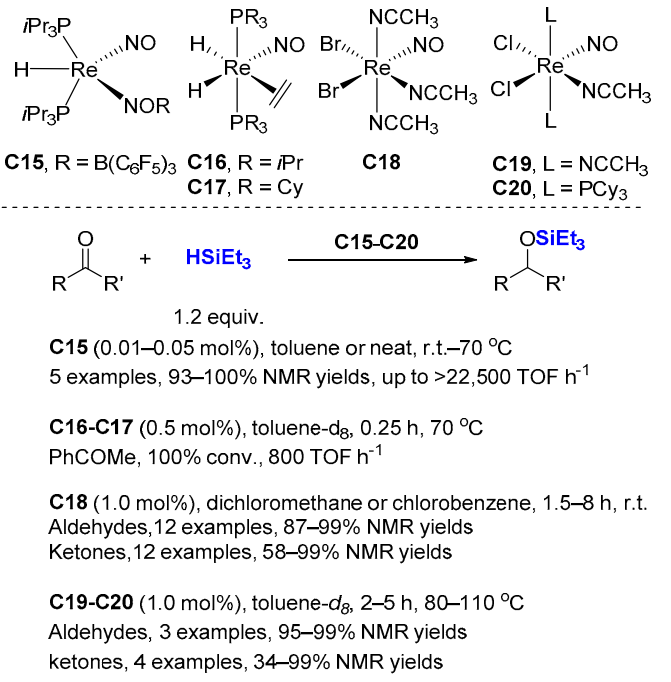

b)

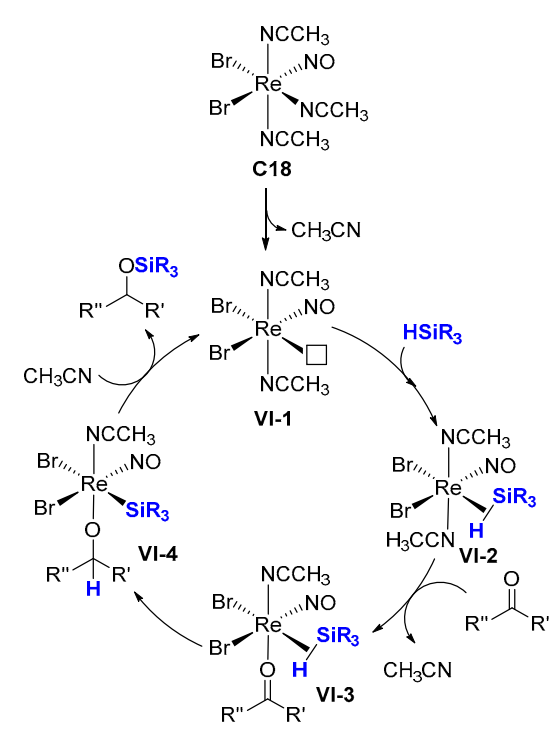

Scheme 8. Rhenium oxides catalyzed hydrosilylation of carbonyl compounds. (a) Scope of the reaction; (b) Proposed mechanism.

In 2012, carbonyl rhenium(I) complexes, namely $\operatorname{Re}(\mathrm{CO})_{5} \mathrm{Cl}(\mathbf{C} 21)$ and $\operatorname{Re}_{2}(\mathrm{CO})_{10}$ (C22), have been found by Fan and co-workers [48] to be effective catalysts for the hydrosilylation of carbonyl substrates with various silanes and with TOF of $20-25 \mathrm{~h}^{-1}$ for aldehydes (Scheme 9a). In this methodology, $1.0 \mathrm{~mol} \%$ catalyst and a $\mathrm{Et}_{3} \mathrm{SiH}$ :carbonyl ratio of 3:1 were used. When different silanes such as $\mathrm{Ph}_{2} \mathrm{SiH}_{2}$ and $\mathrm{Ph}_{3} \mathrm{SiH}$ were used, a decrease in the corresponding silyl ether yield was observed.

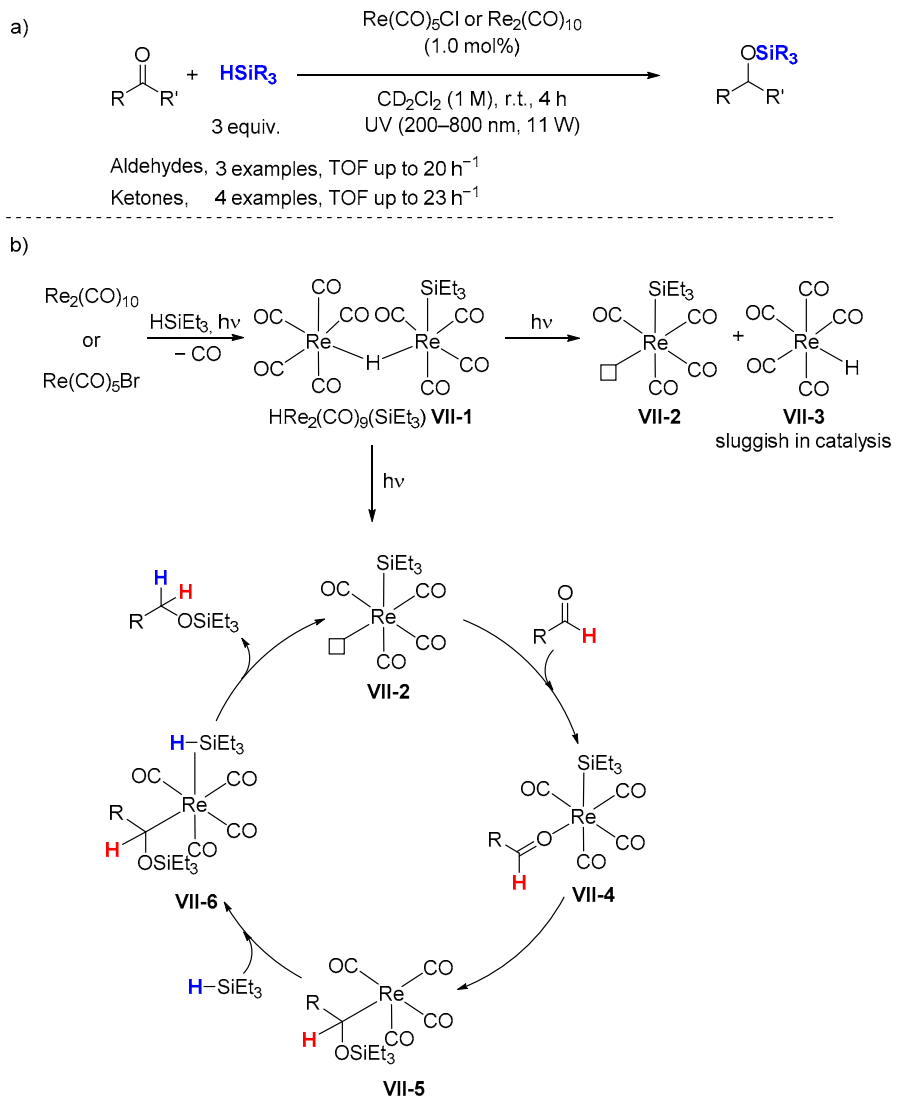

Scheme 9. Hydrosilylation of carbonyls via $\mathrm{Re}(\mathrm{CO})_{5} \mathrm{Cl}$ photolysis (a) and proposed mechanism (b). 
A detailed mechanism for the hydrosilylation of carbonyl compounds was proposed by the same author to account for the experimental observations (Scheme 9b). Upon photolysis of $\mathrm{Et}_{3} \mathrm{SiH}$ with $\mathrm{Re}(\mathrm{CO})_{5} \mathrm{Cl}$ or $\mathrm{Re}_{2}(\mathrm{CO})_{10}$, a dimeric rhenium carbonyl species (VII-1) with a bridging hydride was identified in the mixture. When VII-1 was isolated and tested for aldehyde hydrosilylation, the silyl ether was generated about 2-3 times faster in comparison to $\operatorname{Re}(\mathrm{CO})_{5} \mathrm{Cl}$.

Upon photolysis, the dimer complex VII-1 dissociates to afford $\mathrm{Et}_{3} \mathrm{SiRe}(\mathrm{CO})_{4}(\mathbf{V I I}-\mathbf{2})$ and $\mathrm{HRe}(\mathrm{CO})_{5}$ (VII-3) which was found to be inactive in catalysis. Then, the coordination of the carbonyl substrate to the vacant site of VII-2 facilitates the silyl ligand shift onto the oxygen atom and forms an alkyl ligand bound to the Re center VII-5. Another silane coordinates to the Re center in VII-5 via a $\eta^{2}$-silyl complex or a $\sigma$-silyl $\left(\sigma_{\mathrm{H}}\right)$ complex. Migration of a $\mathrm{H}$ atom from the silane to the alkyl group yields the silyl ether product and regenerates the catalyst VII-2. When either the carbonyl or silane has been depleted, the $\mathrm{Et}_{3} \mathrm{SiRe}(\mathrm{CO})_{4}$ complex(VII-2) coordinates back to $\mathrm{HRe}(\mathrm{CO})_{5}$ (VII-3) and becomes part of the resting state VII-1.

\subsection{Hydrosilylation of Nitriles}

The reduction of nitriles using rhenium are rare. However, in 2011, Fernandes reported a new catalytic system for the reduction of nitriles into the corresponding primary amines with silane as a reducing agent and catalyzed by oxo-rhenium complexes. Using $(10 \mathrm{~mol} \%)$ of rhenium(V)-dioxo complex $\mathbf{C 1}$ and 3 equiv. of phenylsilane in refluxing toluene under air atmosphere, a large range of nitriles bearing functional groups, such as halogen derivatives, $\mathrm{OCH}_{3}, \mathrm{SCH}_{3}, \mathrm{SO}_{2} \mathrm{CH}_{3}$ and NHTs, was reduced with high chemoselectivity (Scheme 10a) [49].

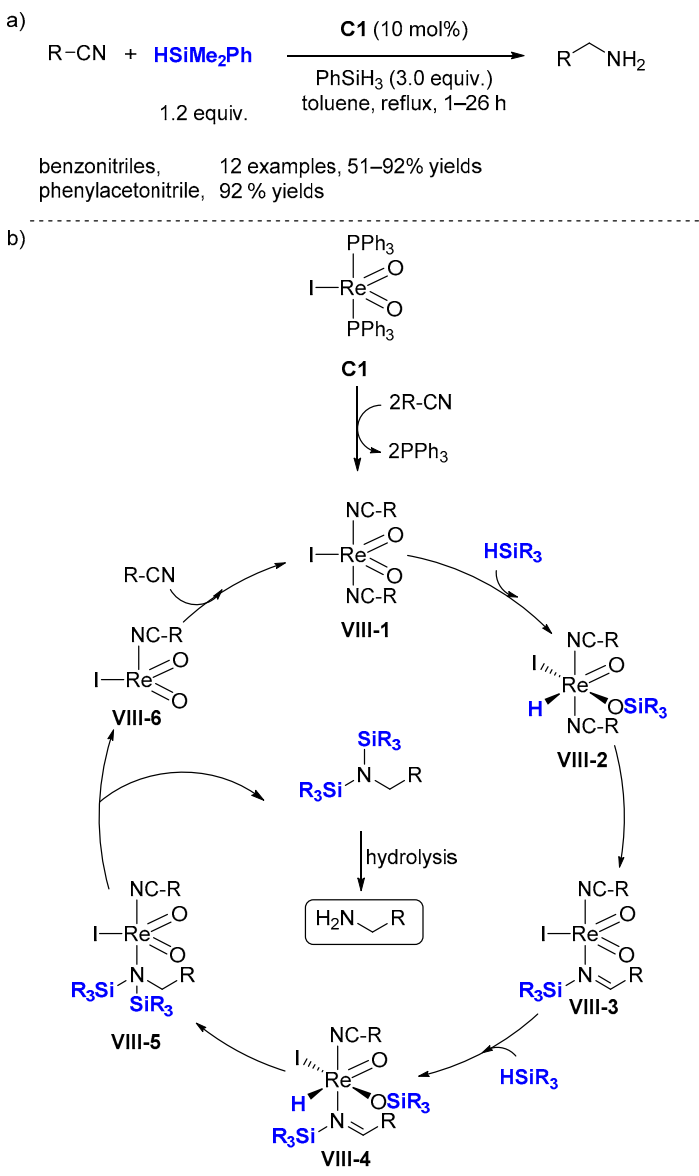

Scheme 10. Reduction of nitriles with silanes and $\mathrm{ReIO}_{2}\left(\mathrm{PPh}_{3}\right)_{2}$ (a) and proposed catalytic cycle (b). 
Then, the catalytic cycle was proposed by the same author (Scheme 10b): Replacing two phosphine ligands with two nitriles at the rhenium center in $\mathbf{C} \mathbf{1}$ produces complex $\mathrm{ReIO}_{2}$ (nitrile) 2 (VIII-1). The addition of the Si-H bond to one of the oxo-rhenium bond results in the formation of the hydride species (nitrile) $)_{2}(\mathrm{O}) \operatorname{IRe}(\mathrm{H}) \mathrm{OSiR}_{3}$ (VIII-2). Dihydrosilylation of the nitrile to the corresponding $N, N$-disilylamino-rhenium complex VIII-5, followed by hydrolysis of the $N$-disilylamine, affords the primary amine as product.

\subsection{Reductive Amination}

The direct reductive amination of aldehydes with primary and secondary anilines [50], using the same oxorhenium complex $\mathbf{C 1}$, was achieved by the group of Fernandes. A large variety of functional groups, such as nitro, sulfone, ester, nitrile, amide, halides including iodide, were well tolerated, using $2.5 \%$ of catalyst loading under refluxing THF for $5 \mathrm{~min}$ to $7 \mathrm{~h}$ (Scheme 11) [51]. The same mechanism as in Scheme 10 was proposed by the authors. In 2013, the same group has reported a series of oxorhenium complexes containing heterocyclic ligands, which were found to also be very efficient catalysts for such transformation. For instance, similar efficiency and chemoselectivity were obtained with the oxo-rhenium complex $\left[\operatorname{ReOBr}_{2}(\mathrm{~L})\left(\mathrm{PPh}_{3}\right) \mathbf{C} 23\left(\mathrm{~L}=2-\left(2^{\prime}-\right.\right.\right.$ hydroxy-5'methylphenyl)benzotriazole) (Scheme 11) [52].

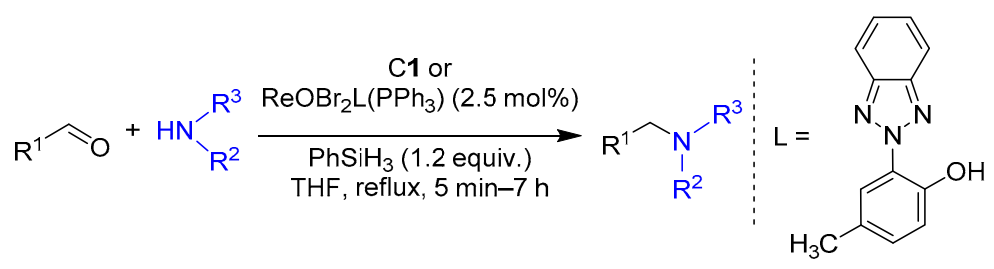

Scheme 11. Direct reductive amination of aldehydes using silane/oxorhenium system.

Furthermore, in 2013, Ghorai reported a direct reductive amination of ketones such as alkanones and cycloalkanones with electron-deficient amines using $\operatorname{Re}_{2} \mathrm{O}_{7}(1.5 \mathrm{~mol} \%)$ and $\mathrm{NaPF}_{6}(20 \mathrm{~mol} \%)$ as the catalytic system and triethylsilane (1.2 equiv.) as the reductant in dichloromethane at $50{ }^{\circ} \mathrm{C}$ for $12-60 \mathrm{~h}$ (Scheme 12) [53]. Excellent diastereoselective reductive amination of 2-alkyl cyclohexanones was also observed, the formation of cisselective 2-alkyl amines was obtained with high chemoselectivity (up to >1:99).

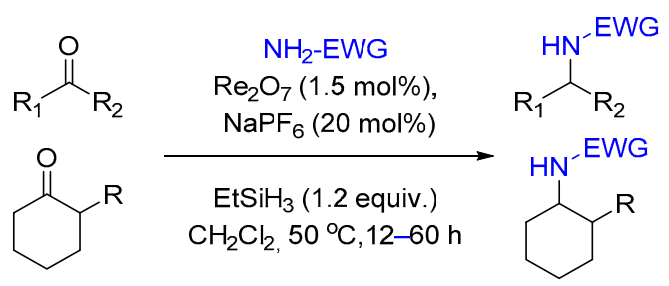

Scheme 12. Direct reductive amination of ketones with electron-deficient amines using $\operatorname{Re}_{2} \mathrm{O}_{7} / \mathrm{NaPF}_{6}$ catalyst system.

\subsection{Hydrosilylation of Nitro Derivatives}

In 2009, the group of Fernandes also reported the reduction of aromatic nitro compounds to the corresponding amines with silanes catalyzed by high valent oxo-rhenium complexes $\mathbf{C} 1$ or $\mathbf{C} 4$ in the presence of 3.6 equiv. of $\mathrm{PhMe}_{2} \mathrm{SiH}$ in refluxing toluene conditions for 1-48 h (Scheme 13) [54]. Aniline derivatives were then isolated in moderate to good yields (31-96\%). It is noticeable that this catalytic transformation tolerated a huge variety of functional groups such as halides, esters, amides, sulfones and nitriles. By contrast, the hydrosilylation of nitroalkanes, such as 2-nitroethylbenzene, led to the corresponding nitrile in $38 \%$ yield. 


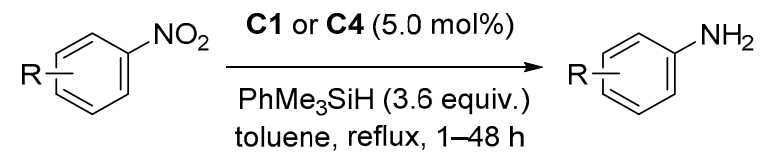

Scheme 13. Reduction of aromatic nitro compounds with $\mathbf{C} 1$ or $\mathbf{C 4}$.

\subsection{Hydrosilylation of Carboxyl Acids Derivatives}

Following our study of the hydrosilylation of various carboxylic acids catalyzed with $\mathrm{Mn}_{2}(\mathrm{CO})_{10}$ [55], our group recently reported the direct reduction of carboxylic acids [56] and esters [57] catalyzed by $\operatorname{Re}_{2}(\mathrm{CO})_{10}$, under mild conditions (r.t., irradiation 350, 395, or $365 \mathrm{~nm})$, with low catalyst loading $(0.5 \mathrm{~mol} \%)$ in the presence of a stoichiometric amount of $\mathrm{Et}_{3} \mathrm{SiH}$ as a reducing agent (Scheme 14). A large variety of carboxylic acids and esters was reduced in moderate to good yields to the corresponding protected aldehydes without noticeable formation of silylethers arising from over-reduction. Good functional group tolerance was achieved over amino, halogeno, isolated $\mathrm{C}=\mathrm{C}$ as well as heteroaromatic groups. In addition, this new protocol was applied to a range of benzoic acid derivatives that are reluctant to be reduced by traditional methods with more drastic conditions: $\operatorname{Re}_{2}(\mathrm{CO})_{10}(5 \mathrm{~mol} \%), \mathrm{Ph}_{2} \mathrm{MeSiH}$ (4.0 equiv.) to afford the corresponding aldehydes after acid treatment (Scheme 14a).

a)

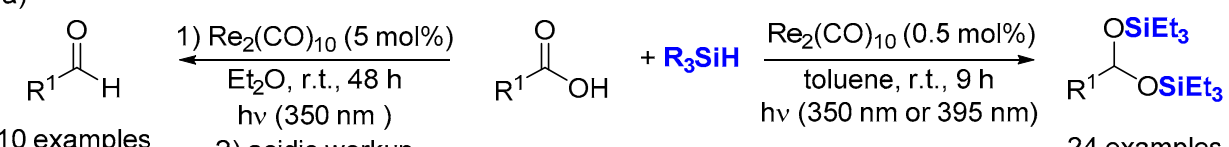

$$
\begin{aligned}
& \text { 2) acidic workup } 24 \text { examples } \\
& \mathrm{R}^{1}=\text { aryl, } \mathrm{Ph}_{2} \mathrm{MeSiH} \quad \mathrm{R}^{1}=\text { alkyl, } \mathrm{Et}_{3} \mathrm{SiH}
\end{aligned}
$$

b)

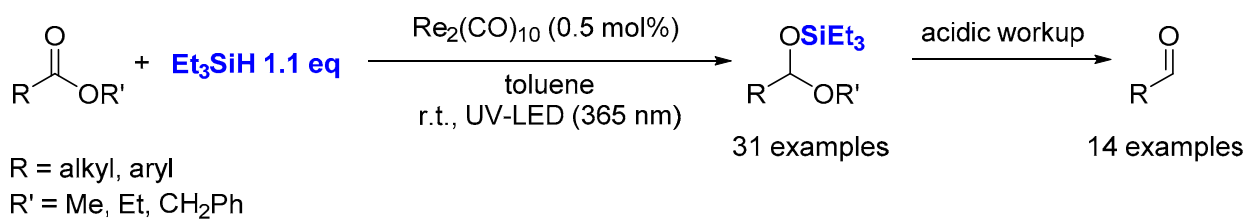

Scheme 14. Rhenium-catalyzed chemoselective reduction of carboxylic acids (a) and esters (b) to aldehydes with hydrosilanes.

\section{Hydrosilylation of $\mathrm{C}=\mathrm{C}$ Bonds}

\subsection{Hydrosilylation of Alkenes}

Despite the importance of the hydrosilylation of alkenes for the production of silicones, only limited examples have been reported with rhenium catalysts in contrast to the hydro-elementation of polar bonds. In 2006, the group of Hua reported the addition of hydrosilanes to styrenes catalyzed by low-valent rhenium complexes, such as $\operatorname{Re}(\mathrm{CO})_{5} \mathrm{Br}(\mathrm{C} 24)$, to selectively afford anti-Markovnikov adducts in good to high yields (Scheme 15) [58]. For the hydrosilylation of styrenes, 1.2 equiv. of $\mathrm{HSiMePh}_{2} \mathrm{was}_{\mathrm{em}-}$ ployed at $120^{\circ} \mathrm{C}$ in toluene $(1 \mathrm{M})$ for $10 \mathrm{~h}$. It is worth mentioning that other rhenium complexes, such as $\operatorname{Re}(\mathrm{CO})_{5} \mathrm{Cl}(\mathbf{C 2 1})$ and $\mathrm{Re}_{2}(\mathrm{CO})_{10}(\mathbf{C 2 2})$, also showed catalytic activity for the hydrosilylation of styrenes, although less actively than $\mathbf{C 2 4}$, to give silylated alkanes in moderate yields as well as a slightly decreased selectivity. However, $\mathrm{CpRe}(\mathrm{CO})_{3}(\mathbf{C} 25)$ and $\mathrm{NH}_{4} \mathrm{ReO}_{4}(\mathbf{C 2 6})$ did not show any catalytic activity at all in such a transformation. Aliphatic alkenes, such as 1-octene and methyl methacrylate, were reduced to their corresponding adducts in poor yields (30\% and $28 \%$, respectively). 


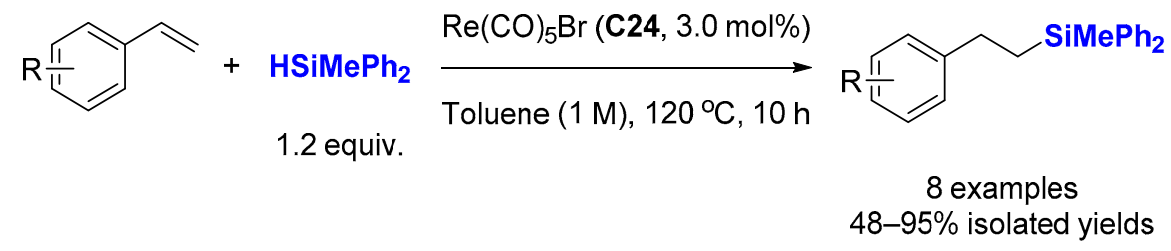

Scheme 15. $\operatorname{Re}(\mathrm{CO})_{5} \mathrm{Br}$-catalyzed hydrosilylation of styrenes.

Interestingly, rhenium mono-nitrosyl complex C16 developed by Berke et al., can also promote the catalytic hydrosilylation of cyclohexene [45] (Scheme 16a) under similar conditions that those employed for ketones $\left(0.5 \mathrm{~mol} \%\right.$ cat., $\left.80^{\circ} \mathrm{C}, 3 \mathrm{~h}\right)$. This process was investigated theoretically by the group of $\mathrm{Li}$ with ethylene and trimethylsilane as model reactants (Scheme 16b) [59]. The proposed catalytic cycle starts with the insertion of the ethylene ligand into the Re-H bond, followed by the cleavage of the agostic interaction involved in VIII-1 to afford VIII-2. Then, a silane molecule coordinates to the Re center to give a $\sigma$ complex VIII-3. The next step involves an oxidative addition process to afford a seven coordinate complex VIII-4. Last step consists of a reductive elimination process to form the product. The catalytic cycle completes by coordination of an ethylene to VIII-5.
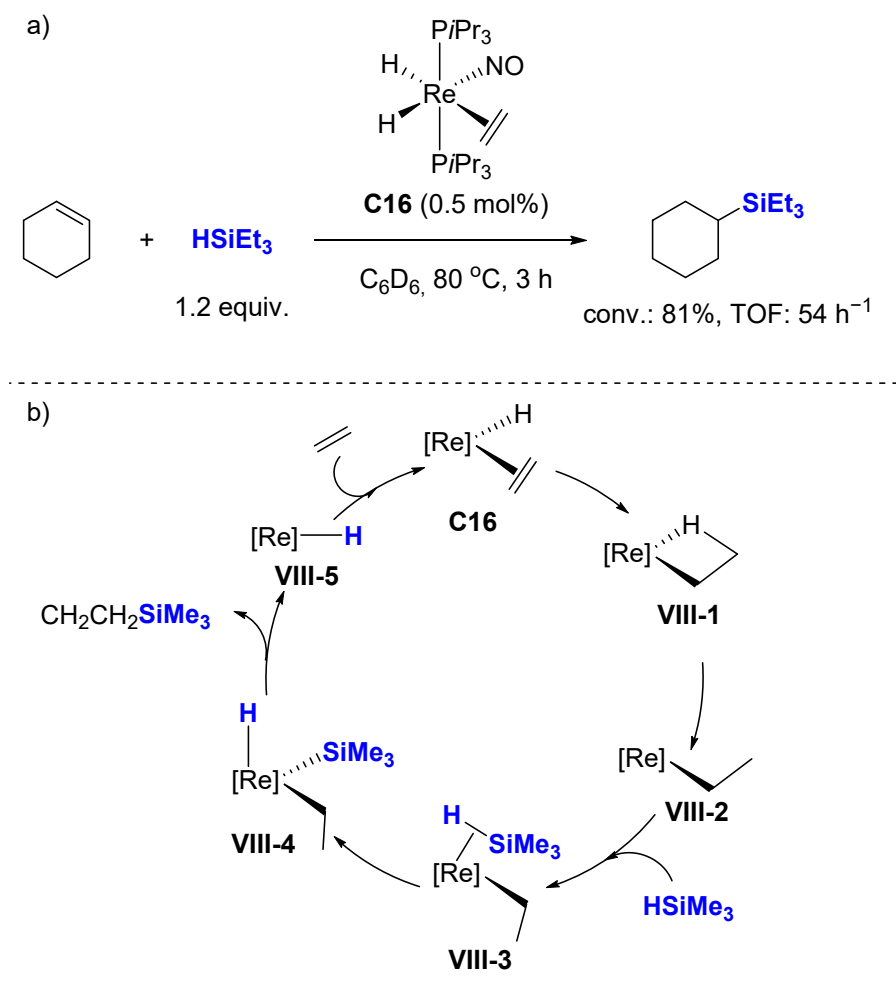

Scheme 16. Rhenium mono-nitrosyl complex catalyzed hydrosilylation of alkenes (a) and proposed mechanism (b).

In 2014, the same group reported a highly selective hydrosilylation of acrylonitrile and its derivatives catalyzed by C18 (1.5 mol\%) by reaction with alkyl or aryl silanes (1 equiv.) at $60-115{ }^{\circ} \mathrm{C}$ in $8-48 \mathrm{~h}$ (Scheme 17) [60]. The regioselectivity of all the reactions were found to be around $\alpha: \beta=3: 1$. Improved regioselectivity was obtained with a high ratio of acrylonitrile:silane. 


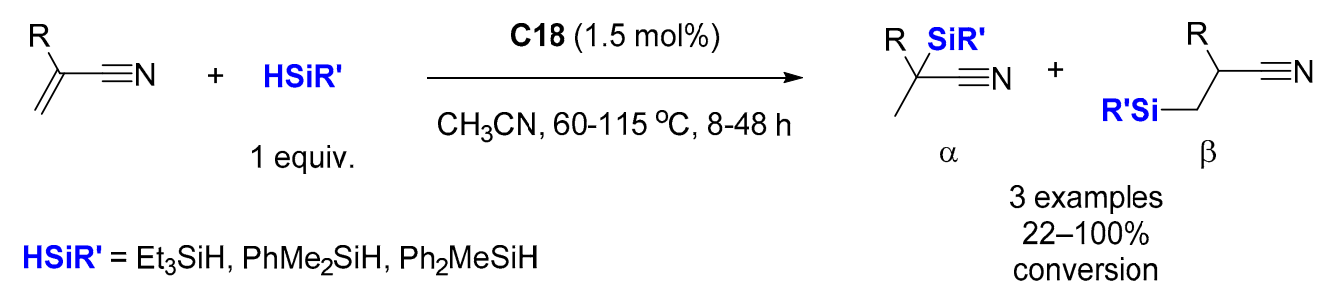

Scheme 17. Re-catalyzed hydrosilylation of nitrile substituted olefins.

\subsection{Dehydrogenative Silylation of Alkenes}

Dehydrogenative silylation is often considered an undesired side reaction in the hydrosilylation of alkenes, but the selective production of vinylsilanes is also a valuable transformation. In this context; Berke et al. reported several rhenium mono-nitrosyl complexes (C18 [60], C19-C20 [47], C25-C26 [61], C27-C28 [62]) catalyzing the dehydrogenative silylation of alkenes with high chemoselectivity to produce silyl alkenes, along with the corresponding alkanes, with $1.0-4.0 \mathrm{~mol} \%$ cat., at $70-110{ }^{\circ} \mathrm{C}$ in toluene- $d_{8}$ (Scheme 18). Hydrosilylation products appear only rarely in very minor amounts. The complexes C19C20 and C27-C28 gave better $E / Z$ selectivity (96:4 $\rightarrow$ 99:1). Noticeably, ethylene can be transformed quantitatively into the corresponding dehydrogenative silylation product with C27-C28 as catalysts with a ratio dehydro/hydro silylation products of 79:21 and 68:32, respectively. C18 catalyzes the dehydrogenative coupling of styrene derivatives with $\mathrm{HSiMe}_{2} \mathrm{Ph}$ leading to dehydro/hydro silylation products in ratio of about 85/15.

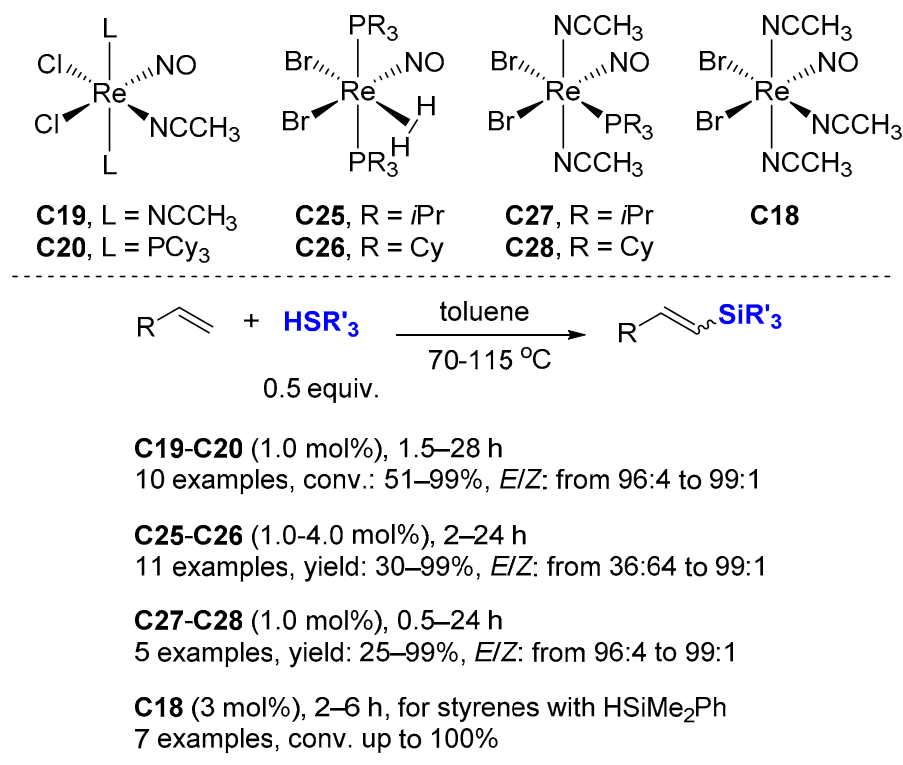

Scheme 18. Rhenium mono-nitrosyl complexes catalyzed dehydrogenative silylation of alkenes.

\section{Conclusions}

In conclusion, we have highlighted in this review the diversity of rhenium complexes that can be encountered as pre-catalysts for hydrosilylation reactions. The oxidation state of the reported catalysts spans from $+\mathrm{VII}$ to $+\mathrm{I}$ leading to an extraordinary variety of coordination complexes, but also diverse mechanisms. It is now evident that rhenium can be an alternative to noble metals for hydrosilylation reactions, but we strongly believe that this less-studied metal also has great potential to discover new or complementary reactivity and selectivity in this field, in particular for alkyne derivatives and in other catalytic processes. 
Author Contributions: Collecting of the data and original draft preparation, D.W. and R.B.; conceptualization, methodology of this review, writing-review and editing, funding acquisition, Y.C. and J.-B.S. All authors have read and agreed to the published version of the manuscript.

Funding: This research was funded by the Centre National de la Recherche Scientifique (CNRS), the Université de Rennes 1, the Université Toulouse III, Paul Sabatier, and the Institut Universitaire de France (IUF) (general support). R.B. is grateful to the Embassy of Yemen in Paris, and the program Pause, Collège de France, for financial support.

Conflicts of Interest: The authors declare no conflict of interest.

\section{References}

1. Marciniec, B. Catalysis of hydrosilylation of carbon-carbon multiple bonds: Recent progress. Silicon Chem. 2002, 1, 155-174. [CrossRef]

2. Roy, A.K. A Review of Recent Progress in Catalyzed Homogeneous Hydrosilation (Hydrosilylation). Adv. Organomet. Chem. 2007, 55, 1-59. [CrossRef]

3. Nakajima, Y.; Shimada, S. Hydrosilylation reaction of olefins: Recent advances and perspectives. RSC Adv. 2015, 5, 20603-20616. [CrossRef]

4. Tamang, S.R.; Findlater, M. Emergence and Applications of Base Metals (Fe, Co, and Ni) in Hydroboration and Hydrosilylation. Molecules 2019, 24, 3194. [CrossRef]

5. Du, X.; Huang, Z. Advances in Base-Metal-Catalyzed Alkene Hydrosilylation. ACS Catal. 2017, 7, 1227-1243. [CrossRef]

6. Obligacion, J.V.; Chirik, P.J. Earth-abundant transition metal catalysts for alkene hydrosilylation and hydroboration. Nat. Rev. Chem. 2018, 2, 15-34. [CrossRef]

7. Valyaev, D.A.; Lavigne, G.; Lugan, N. Manganese organometallic compounds in homogeneous catalysis: Past, present, and prospects. Coord. Chem. Rev. 2016, 308, 191-235. [CrossRef]

8. Kuninobu, Y.; Takai, K. Organic Reactions Catalyzed by Rhenium Carbonyl Complexes. Chem. Rev. 2011, 111, 1938-1953. [CrossRef] [PubMed]

9. Harms, R.G.; Herrmann, W.A.; Kühn, F.E. Organorhenium dioxides as oxygen transfer systems: Synthesis, reactivity, and applications. Coord. Chem. Rev. 2015, 296, 1-23. [CrossRef]

10. Owens, G.S.; Arias, J.; Abu-Omar, M.M. ChemInform Abstract: Rhenium Oxo Complexes in Catalytic Oxidations. ChemInform 2010, 31, 317-363. [CrossRef]

11. Romão, C.C.; Kühn, F.E.; Herrmann, W.A. Rhenium(VII) Oxo and Imido Complexes: Synthesis, Structures, and Applications. Chem. Rev. 1997, 97, 3197-3246. [CrossRef]

12. Espenson, J.H. Atom-transfer reactions catalyzed by methyltrioxorhenium(VII)-mechanisms and applications. Chem. Commun. 1999, 6, 479-488. [CrossRef]

13. Fuchs, P.L. Catalytic Oxidation Reagents; John Wiley \& Sons: Chichester, UK, 2013.

14. Yudin, A.K.; Sharpless, K.B. Bis(trimethylsilyl) Peroxide Extends the Range of Oxorhenium Catalysts for Olefin Epoxidation. J. Am. Chem. Soc. 1997, 119, 11536-11537. [CrossRef]

15. Herrmann, W.A.; Kuchler, J.G.; Felixberger, J.K.; Herdtweck, E.; Wagner, W. Methylrhenium Oxides: Synthesis from R2O7 and Catalytic Activity in Olefin Metathesis. Angew. Chem. Int. Ed. 1988, 27, 394-396. [CrossRef]

16. Herrmann, W.A.; Roesky, P.W.; Wang, M.; Scherer, W. Multiple Bonds between Main-Group Elements and Transition Metals. 135. Oxorhenium(V) Catalysts for the Olefination of Aldehydes. Organometallics 1994, 13, 4531-4535. [CrossRef]

17. Volkert, W.A.; Hoffman, T.J. Therapeutic radiopharmaceuticals. Chem. Rev. 1999, 99, 2269-2292. [CrossRef]

18. Dilworth, J.R.; Parrott, S.J. The biomedical chemistry of technetium and rhenium. Chem. Soc. Rev. 1998, 27, 43-55. [CrossRef]

19. Du, G.; Abu-Omar, M.M. ChemInform Abstract: Oxo and Imido Complexes of Rhenium and Molybdenum in Catalytic Reductions. Chemistry 2009, 40, 1185-1198. [CrossRef]

20. Kobayashi, Y. Reduction with Hydrosilanes Catalyzed by Metal-oxo Complexes. J. Synth. Org. Chem. Jpn. 2010, 68, 866-867. [CrossRef]

21. Kennedy-Smith, J.J.; Nolin, K.A.; Gunterman, H.P.; Toste, F.D. Reversing the Role of the Metal-Oxygen $\pi$-Bond. Chemose-lective Catalytic Reductions with a Rhenium(V)-Dioxo Complex. J. Am. Chem. Soc. 2003, 125, 4056-4057. [CrossRef]

22. Thiel, W.R. On the Way to a New Class of Catalysts-High-Valent Transition-Metal Complexes That Catalyze Reductions. Angew. Chem. Int. Ed. 2003, 42, 5390-5392. [CrossRef]

23. Yang, X.; Wang, C. Manganese-Catalyzed Hydrosilylation Reactions. Chem. Asian J. 2018, 13, 2307-2315. [CrossRef]

24. Royo, B. Recent advances in catalytic hydrosilylation of carbonyl groups mediated by well-defined first-row late transition metals. Adv. Organomet. Chem. 2019, 72, 59-102.

25. Nolin, K.A.; Krumper, J.R.; Pluth, M.D.; Bergman, A.R.G.; Toste, F.D. Analysis of an Unprecedented Mechanism for the Catalytic Hydrosilylation of Carbonyl Compounds. J. Am. Chem. Soc. 2007, 129, 14684-14696. [CrossRef] [PubMed]

26. Chung, L.W.; Lee, H.G.; Lin, Z.; Wu, Y.-D. Computational Study on the Reaction Mechanism of Hydrosilylation of Carbonyls Catalyzed by High-Valent Rhenium(V)-Di-oxo Complexes. J. Org. Chem. 2006, 71, 6000-6009. [CrossRef] 
27. Huang, L.; Wang, W.; Wei, X.; Wei, H. New Insights into Hydrosilylation of Unsaturated Carbon-Heteroatom (C=O, C=N) Bonds by Rhenium(V)-Dioxo Complexes. J. Phys. Chem. A 2015, 119, 3789-3799. [CrossRef]

28. Royo, B.; Romão, C.C. Reduction of carbonyl groups by high-valent rhenium oxides. J. Mol. Catal. A Chem. 2005, 236, 107-112. [CrossRef]

29. Ison, E.A.; Trivedi, E.R.; Corbin, R.A.; Abu-Omar, M.M. Mechanism for Reduction Catalysis by Metal Oxo: Hydrosilation of Organic Carbonyl Groups Catalyzed by a Rhenium(V) Oxo Complex. J. Am. Chem. Soc. 2005, 127, 15374-15375. [CrossRef] [PubMed]

30. Ison, E.A.; Corbin, R.A.; Abu-Omar, M.M. Hydrogen Production from Hydrolytic Oxidation of Organosilanes Using a Cationic Oxorhenium Catalyst. J. Am. Chem. Soc. 2005, 127, 11938-11939. [CrossRef] [PubMed]

31. Du, G.; Abu-Omar, M.M. Catalytic Hydrosilylation of Carbonyl Compounds with Cationic Oxorhenium(V) Salen. Organometallics 2006, 25, 4920-4923. [CrossRef]

32. Ison, E.A.; Cessarich, J.E.; Du, G.; Fanwick, A.P.E.; Abu-Omar, M.M. Synthesis of Cationic Oxorhenium Salen Complexes via $\mu-O x o$ Abstraction and Their Activity in Catalytic Reductions. Inorg. Chem. 2006, 45, 2385-2387. [CrossRef] [PubMed]

33. Du, G.; Fanwick, P.E.; Abu-Omar, M.M. Cationic oxorhenium chiral salen complexes for asymmetric hydrosilylation and kinetic resolution of alcohols. Inorg. Chim. Acta 2008, 361, 3184-3192. [CrossRef]

34. Du, G.; Fanwick, P.E.; Abu-Omar, M.M. Mechanistic Insight into Hydrosilylation Reactions Catalyzed by High Valent Re:X $(X=\mathrm{O}$, NAr, or N) Complexes: The Silane (SiH) Does Not Add across the Metal-Ligand Multiple Bond. J. Am. Chem. Soc. 2007, 129, 5180-5187. [CrossRef] [PubMed]

35. Gu, P.; Wang, W.; Wang, Y.; Wei, H. Hydrosilylation of Carbonyls Catalyzed by the Rhenium(V) Oxo Complex [Re(O)(hoz)2]+-A Non-Hydride Pathway. Organometallics 2012, 32, 47-51. [CrossRef]

36. Huang, L.; Zhang, Y.; Wei, H. Role of the Isolable Hydride Intermediate in the Hydrosilylation of Carbonyl Compounds Catalyzed by the High-Valent Mono-Oxido-Rhenium(V) Complex. Eur. J. Inorg. Chem. 2014, 2014, 5714-5723. [CrossRef]

37. Huang, L.; Wang, W.; Wei, H. A computational study on high-valent mono-oxo-rhenium(V) complex-catalyzed hydrosilyla-tion of carbonyls: What a difference an oxo ligand makes. J. Mol. Catal. A Chem. 2015, 400, 31-41. [CrossRef]

38. Nolin, K.A.; Ahn, R.W.; Kobayashi, Y.; Kennedy-Smith, J.J.; Toste, F.D. Enantioselective Reduction of Ketones and Imines Catalyzed by (CN-Box)ReV-Oxo Complexes. Chem. Eur. J. 2010, 16, 9555-9562. [CrossRef]

39. Nolin, K.A.; Ahn, R.W.; Toste, F.D. Enantioselective reduction of imines catalyzed by a Rhenium (V)- Oxo complex. J. Am. Chem. Soc. 2005, 127, 12462-12463. [CrossRef]

40. Wang, J.; Wang, W.; Huang, L.; Yang, X.; Wei, H. The Unexpected Mechanism Underlying the High-Valent Mono-Oxo-Rhenium(V) Hydride Catalyzed Hydrosilylation of C=N Functionalities: Insights from a DFT Study. ChemPhysChem 2015, 16, 1052-1060. [CrossRef]

41. Smeltz, J.L.; Boyle, P.D.; Ison, E.A. Role of Low-Valent Rhenium Species in Catalytic Hydrosilylation Reactions with Ox-orhenium Catalysts. Organometallics 2012, 31, 5994-5997. [CrossRef]

42. Pérez, D.E.; Smeltz, J.L.; Sommer, R.D.; Boyle, P.D.; Ison, E.A. Cationic rhenium(iii) complexes: Synthesis, characterization, and reactivity for hydrosilylation of aldehydes. Dalton Trans. 2017, 46, 4609-4616. [CrossRef]

43. Brown, C.A.; Abrahamse, M.; Ison, E.A. Re-Silane complexes as frustrated lewis pairs for catalytic hydrosilylation. Dalton Trans. 2020, 49, 11403-11411. [CrossRef]

44. Huang, W.; Berke, H. Rhenium Complexes as Highly Active Catalysts for the Hydrosilylation of Carbonyl Compounds. Chim. Int. J. Chem. 2005, 59, 113-115. [CrossRef]

45. Choualeb, A.; Maccaroni, E.; Blacque, O.; Schmalle, H.W.; Berke, H. Rhenium Nitrosyl Complexes for Hydrogenations and Hydrosilylations. Organometallics 2008, 27, 3474-3481. [CrossRef]

46. Dong, H.; Berke, H. A Convenient and Efficient Rhenium-Catalyzed Hydrosilylation of Ketones and Aldehydes. Adv. Synth. Catal. 2009, 351, 1783-1788. [CrossRef]

47. Jiang, Y.; Blacque, O.; Berke, H. Probing the catalytic potential of chloro nitrosyl rhenium(i) complexes. Dalton Trans. 2011, 40, 2578-2587. [CrossRef] [PubMed]

48. Toh, C.K.; Sum, Y.N.; Fong, W.K.; Ang, S.G.; Fan, W.Y. Catalytic Hydrosilylation of Carbonyls via Re(CO)5Cl Photolysis. Organometallics 2012, 31, 3880-3887. [CrossRef]

49. Cabrita, I.; Fernandes, A.C. A novel efficient and chemoselective method for the reduction of nitriles using the system silane/oxorhenium complexes. Tetrahedron 2011, 67, 8183-8186. [CrossRef]

50. Li, B.; Sortais, J.-B.; Darcel, C. Amine synthesis via transition metal homogeneous catalysed hydrosilylation. RSC Adv. 2016, 6, 57603-57625. [CrossRef]

51. Sousa, S.C.; Fernandes, A.C. Efficient and highly chemoselective direct reductive amination of aldehydes using the system silane/oxorhenium complexes. Adv. Synth. Catal. 2010, 352, 2218-2226. [CrossRef]

52. Bernardo, J.R.; Sousa, S.C.A.; Florindo, P.R.; Wolff, M.; Machura, B.; Fernandes, A.C. Efficient and chemoselective direct reductive amination of aromatic aldehydes catalyzed by oxo-rhenium complexes containing heterocyclic ligands. Tetrahedron 2013, 69, 9145-9154. [CrossRef]

53. Das, B.G.; Ghorai, P. Stereoselective direct reductive amination of ketones with electron-deficient amines using Re2O7/NaPF6 catalyst. Org. Biomol. Chem. 2013, 11, 4379-4382. [CrossRef] [PubMed] 
54. de Noronha, R.G.; Romão, C.C.; Fernandes, A.C. Highly Chemo- and Regioselective Reduction of Aromatic Nitro Compounds Using the System Silane/Oxo-Rhenium Complexes. J. Org. Chem. 2009, 74, 6960-6964. [CrossRef]

55. Zheng, J.; Chevance, S.; Darcel, C.; Sortais, J.-B. Selective reduction of carboxylic acids to aldehydes through manganese catalysed hydrosilylation. Chem. Commun. 2013, 49, 10010-10012. [CrossRef] [PubMed]

56. Wei, D.; Buhaibeh, R.; Canac, Y.; Sortais, J.-B. Rhenium-Catalyzed Reduction of Carboxylic Acids with Hydrosilanes. Org. Lett. 2019, 21, 7713-7716. [CrossRef]

57. Wei, D.; Buhaibeh, R.; Canac, Y.; Sortais, J.-B. Manganese and rhenium-catalyzed selective reduction of esters to aldehydes with hydrosilanes. Chem. Commun. 2020, 56, 11617-11620. [CrossRef]

58. Zhao, W.-G.; Hua, R. Highly regioselective rhenium-catalyzed hydrosilylation of styrenes. Eur. J. Org. Chem. 2006, 5495-5498. [CrossRef]

59. Liu, L.; Bi, S.; Sun, M.; Yuan, X.; Zheng, N.; Li, P. Mechanistic investigation on hydrogenation and hydrosilylation of ethylene catalyzed by rhenium nitrosyl complex. J. Organomet. Chem. 2009, 694, 3343-3348. [CrossRef]

60. Dong, H.; Jiang, Y.; Berke, H. Rhenium-mediated dehydrogenative silylation and highly regioselective hydrosilylation of nitrile substituted olefins. J. Organomet. Chem. 2014, 750, 17-22. [CrossRef]

61. Jiang, Y.; Blacque, O.; Fox, T.; Frech, C.M.; Berke, H. Highly selective dehydrogenative silylation of alkenes catalyzed by rhenium complexes. Chem. Eur. J. 2009, 15, 2121-2128. [CrossRef]

62. Jiang, Y.; Blacque, O.; Fox, T.; Frech, C.M.; Berke, H. Facile Synthetic Access to Rhenium(II) Complexes: Activation of CarbonBromine Bonds by Single-Electron Transfer. Chem. A Eur. J. 2010, 16, 2240-2249. [CrossRef] [PubMed] 